http://jmscr.igmpublication.org/home/ ISSN (e)-2347-176x ISSN (p) 2455-0450

crossref DOI: https://dx.doi.org/10.18535/jmscr/v7i9.27

\author{
Journal Of Medical Science And Clinical Research \\ IGM Publication \\ An official Publication of IGM Publication
}

\title{
Bupivacaine Induced Aseptic Meningitis
}

\author{
Authors \\ Dr Vandana Avinash Badar ${ }^{1 *}$, Dr Vidisha Vivek Parulekar ${ }^{2}$, Dr Priti Garate ${ }^{3}$ \\ ${ }^{1}$ Associate Professor, ${ }^{2,3}$ Resident \\ Department of Pharmacology, Indira Gandhi Government Medical College, Nagpur \\ *Corresponding Author \\ Dr Vandana Avinash Badar
}

\begin{abstract}
Bupivacaine is a longer acting amide local anesthetic most commonly used for spinal and epidural anesthesia. A 55yr old male patient was scheduled for hernia surgery on 13/12/16. Following premedication with ondensetron $4 \mathrm{mg} I V$, spinal anesthesia with $3.5 \mathrm{ml}$ of $0.5 \%$ Bupivacaine heavy (bupivacaine $5 \mathrm{mg} / \mathrm{ml}$ and anhydrous dextrose $80 \mathrm{mg} / \mathrm{ml}$ ) and inj.Buprenorphine $75 \mu \mathrm{g}$ was administered in the L3-4 space with aseptic precautions. He also received inj.Amoxycillin and Clavulinic acid 1.2g during surgery. Two hours post-operatively, he complained of frontal headache- mild intensity, even in supine position which was treated with inj.Paracetamol $1 \mathrm{~g} I V$. There was no neck rigidity. After around an hour, he had nausea following which he had 3 bouts of vomiting. Four hours postoperatively, he developed rigors which gradually progressed to irritability. At the fifth hour postoperatively, he was disoriented and drowsy. A cerebrospinal fluid analysis revealed $\mathrm{pH}: 7.5$, glucose $18.1 \mathrm{mg} / 100 \mathrm{~mL}$, proteins $494.7 \mathrm{mg} / 100 \mathrm{~mL}$, a total leucocyte count of 4000/mm3 with $90 \%$ polymorphs and red blood cell count of $80 / \mathrm{mm} 3$ and gram stain- negative. The serum electrolytes were normal $(\mathrm{Na} 138.4 \mathrm{mEq} / \mathrm{L}$ and Sr. K $3.51 \mathrm{mEq} / \mathrm{L})$. After the second dose of dexamethasone $8 \mathrm{mg}$, he was shifted in the room and discharged. CSF culture revealed no growth. Seriousness of reaction was that intervention was required. Outcome of reaction was that patient recovered after 2 days. The reaction is certain according to WHO-UMC causality scale. Bupivacaine as a single agent should be screened for toxicity for individual factors like $\mathrm{pH}$, osmolarity, the chemical vehicle, consequences of use of needles and catheters to place the drug and even patient's preexisting pathological state. Aseptic meningitis is a rare and not very common complication of spinal anesthesia but if suspected postoperatively then early diagnosis and timely management should be commenced in order to avoid further complications.

Keywords: local anesthetic, WHO-UMC causality scale, bupivacaine, aseptic meningitis.
\end{abstract}

\section{Introduction}

Bupivacaine is a longer acting amide local anesthetic most commonly used for spinal and epidural anesthesia. Bupivacaine induced aseptic meningitis (AM) has been reported. This is characterized by negative bacterial and viral growth on CSF culture and can completely recover with early diagnosis and prompt treatment.

\section{Case Report}

A 55yr old male patient was scheduled for hernia surgery on 13/12/16. Following premedication with ondensetron $4 \mathrm{mg} I V$, spinal anesthesia with 
$3.5 \mathrm{ml}$ of $0.5 \%$ Bupivacaine heavy (bupivacaine $5 \mathrm{mg} / \mathrm{ml}$ and anhydrous dextrose $80 \mathrm{mg} / \mathrm{ml}$ ) and inj.Buprenorphine $75 \mu \mathrm{g}$ was administered in the L3-4 space with aseptic precautions. $\mathrm{He}$ also received inj.Amoxycillin and Clavulinic acid $1.2 \mathrm{mg}$ during surgery. Two hours postoperatively, he complained of frontal headachemild intensity, even in supine position which was treated with inj.Paracetamol $1 \mathrm{~g}$ IV. There was no neck rigidity. After around an hour, he had nausea following which he had 3 bouts of vomiting. Four hours postoperatively, he developed rigors which gradually progressed to irritability. At the fifth hour postoperatively, he was disoriented and drowsy. A cerebrospinal fluid analysis revealed $\mathrm{pH}: 7.5, \quad$ glucose $18.1 \mathrm{mg} / 100 \mathrm{~mL}$, proteins $494.7 \mathrm{mg} / 100 \mathrm{~mL}$, a total leucocyte count of $4000 / \mathrm{mm}^{3}$ with $90 \%$ polymorphs and red blood cell count of $80 / \mathrm{mm}^{3}$ and gram stain- negative. The serum electrolytes were normal (Na 138.4 $\mathrm{mEq} / \mathrm{L}$ and $\mathrm{Sr}$. K $3.51 \mathrm{mEq} / \mathrm{L}$ ). The patient was shifted to intensive care unit and treated with inj.Dexamethasone $8 \mathrm{mg}$ stat, inj.Midazolam $2 \mathrm{mg}$ and an additional antibiotic inj.Ceftriaxone $2 \mathrm{gm}$ BD IV was given. His irritability appeared to improve and after 12 hours, he could obey commands but was completely disoriented. Repeat investigations revealed TLC $13,800 / \mu \mathrm{L}$, neutrophils $88 \%$, lymphocytes $10 \%$, $\mathrm{Hb}-$ $13.2 \mathrm{~g} / \mathrm{dL}$, platelet count- $2,03,000 / \mu \mathrm{L}$. MRI study of brain revealed old ischaemic lesions. After the second dose of dexamethasone $8 \mathrm{mg}$, he was shifted in the room and discharged. CSF culture revealed no growth. Seriousness of reaction was that intervention was required. Outcome of reaction was that patient recovered after 2 days. The reaction is certain according to WHO-UMC causality scale ${ }^{(1)}$.

There had been two such incidences of drug induced AM secondary to bupivacaine before one month. In all there were three similar incidences of drug induced AM due to bupivacaine of same batch and same manufacturing companies. Hence, bupivacaine was suspected drug in this case.
Inj.Buprenorphine was used as a concomitant medication for intra-operative pain and no case of AM has been reported so far due to this drug. However, it can be a suspected drug if it is re-used from pre-used vial. In our case, fresh vial was used so we exclude this as a suspected drug.

Meningitis after spinal and epidural anesthesia is rare but serious complication which requires early detection and expeditious treatment. Despite thorough knowledge and aseptic technique, AM can occur as, in this case, CSF culture revealed no growth. It can occur due to host, drug and environmental factors. AM can also occur due to viral contamination after spinal anesthesia due to substances contaminating subarachnoid space like scrub solutions, surgical glove powder, bits of cotton of wrapped syringes, blood or other body proteins, rarely by anesthetic drugs and equipments. Incidence of AM can be significantly reduced by the use of small bore, blunt needles which produce smaller hole in dura and separates its fibres rather than cutting them ${ }^{(2)}$. Some reactions may occur when multiple dose ampoules are used possibly due to contamination or due to added preservative ${ }^{(3)}$.

In this case, anhydrous dextrose $(80 \mathrm{mg} / \mathrm{ml})$ was used as a vehicle in bupivacaine vial that may have caused AM due to contamination of vehicle. It provides some degree of directional control of local anesthetic and thus the extent and pattern of subsequent spinal block. The pursuit for better vehicle combined with local anesthetics to enhance their clinical actions by facilitating additional effects or increasing duration of action of local anesthetic thus reducing total required anesthetic dose also raises the potential of toxicity from adjuvant itself ${ }^{(4)}$. Thus, the necessary preliminary step for tissue testing for safety with potential analgesic or vehicle must include tests in a variety of animal species before human studies are initiated and complete toxicity profile of the drug and adjuvant must be fully understood ${ }^{(5)}$.

Bupivacaine as a single agent should be screened for toxicity for individual factors like $\mathrm{pH}$, osmolarity, the chemical vehicle, consequences of 
use of needles and catheters to place the drug and even patient's preexisting pathological state. Aseptic meningitis is a rare and not very common complication of spinal anesthesia but if suspected postoperatively then early diagnosis and timely management should be commenced in order to avoid further complications.

Sources of support in the form of grants - nil

\section{References}

1. Organization WH. The use of the WHOUMC system for standardized case causality assessment. Uppsala Uppsala Monit Cent [Internet]. 2005;(3):2-7. Available from: http://whoumc.org/Graphics/24734.pdf\%5Cnhttp://sc holar.google.com/scholar?hl=en\&btnG=Se arch\&q=intitle:The+use+of +the+WHO$\mathrm{UMC}+$ system+for+standardised+case+cau sality+assessment\#0

2. S S, Martindale. The complete drug reference. 37th ed. Sweetman SC, editor. Vol. A. London, England: UK: Pharmaceutical Press; 2012. 2783 p.

3. Calvey N, Norway W, Principles and Practice of Pharmacology for Anesthesia, $5^{\text {th }}$ edition, page no.160,2008 Calvey N, Williams N. Principles and Practice of Pharmacology for Anesthesia. 5th ed. Wiley-Blackwell; 2008. 160 p.

4. Flood P, Rathmell JP, Shafer S. Pharmacology and physiology in anesthetic practice. 5th ed. Philadelphia: Wolters Kulver Heath; 2015. 292 p.

5. Neal JM, Rathmell JP. Complication of regional anesthesia and pain medicine. 2nd ed. Philadelphia: Lippincott Williams and Wilkins, a Walters Kulver business; 2013. 72-96 p. 